\title{
PERTUMBUHAN DAN HASIL BERBAGAI VARIETAS KACANG HIJAU ANTARA SISTEM MONOCROP DAN PENANAMAN BERSAMA PADI BERAS MERAH PADA SISTEM IRIGASI AEROBIK
}

\section{GROWTH AND YIELD OF VARIOUS MUNGBEAN VARIETIES BETWEEN MONOCROP AND GROWING TOGETHER WITH RED RICE IN AEROBIC IRRIGATION SYSTEM}

\author{
Dian Mayasari ${ }^{1}$, Wayan Wangiyana ${ }^{2 *}$ \\ ${ }^{1}$ Alumnus Fakultas Pertanian, Universitas Mataram \\ ${ }^{2}$ Dosen Fakultas Pertanian, Universitas Mataram \\ "E-mail: w.wangiyana@unram.ac.id
}

\begin{abstract}
ABSTRAK
Penelitian ini bertujuan untuk membandingkan pertumbuhan dan komponen hasil berbagai varietas kacang hijau antara penanaman secara monokrop dan penanaman bersama padi beras merah pada sistem aerobik, dengan melaksanakan percobaan penanaman di pot dalam rumah plastik di Dasan Tebu, Kecamatan Kediri, Lombok Barat, dari bulan Mei sampai September 2017. Percobaan ditata menurut Rancangan Acak Lengkap (RAL) dengan tiga ulangan dan dua faktor perlakuan yang ditata secara faktorial, yaitu varietas kacang hijau (varietas No.129, Merak, Vima-3, Vima-1 dan Kenari) dan pola tanam (secara monokrop dan penanaman bersama padiberas merah). Data dianalisis analisis keragaman dan uji Beda Nyata Jujur (BNJ) pada taraf nyata 5\% menggunakan program statistik CoStat for Windows ver. 6.303. Hasil penelitian menunjukkan bahwa ada perbedaan respon antar beberapa varietas kacang hijau terhadap pola penanaman bersama padi beras merah dalam kaitan dengan pertumbuhan dan hasil biji kacang hijau. Kacang hijau varietas No.129 menunjukkan hasil biji yang lebih tinggi pada pola penanaman bersama padi beras merah (11,78 g/pot), sebaliknya varietas Vima-1 hasil bijinya lebih rendah dan terendah $(6,5 \mathrm{~g} / \mathrm{pot}) \mathrm{pada}$ penanaman bersama padi beras merah dibandingkan pada sistem monokrop $(9,32 \mathrm{~g} / \mathrm{pot})$, sedangkan varietas Vima-3 menunjukkan hasil biji yang tidak berbeda nyata antara penanaman bersama padi beras merah $(11,66 \mathrm{~g} / \mathrm{pot})$ dan sistem monokrop $(10,09 \mathrm{~g} / \mathrm{pot})$. Oleh karena itu perlu pengujian lapangan untuk menemukan lebih banyak lagi varietas kacang hijau yang toleran untuk ditanam bersama padi pada sistem tumpangsari.
\end{abstract}

Kata Kunci: Kacang Hijau, Pola Tanam, Padi Sistem Aerobik, Tumpangsari

\section{ABSTRACT}

This study aimed to compare growth and yield components of various mungbean varieties between growing in monocrop and growing together with red rice in aerobic irrigation system, by carrying out pot experiment in a plastic house located in Dasan Tebu village of Kediri District, in West Lombok, from May to September 2017. The experiment was designed according to the Completely Randomized Design (CRD) with three replications and two treatment factors arranged factorially, namely mungbean varieties (varieties of No.129, Merak, Vima-3, Vima-1, and Kenari) and planting patterns (in monocrop and growing together with rice). Data were analyzed with analysis of variance (ANOVA) and Honestly Significant Difference test (Tukey's HSD) at 5\% level of significance using the statistical software CoStat for Windows ver. 6.303. The results showed that there were different responses between several mungbean varieties to growing it together with red rice in relation to growth and yield components of mungbean. The mungbean variety No.129 showed higher seed yields when grown together with red rice (11.78 g/pot), whereas seed yield of the Vima-1 variety was lower (i.e. only $6.5 \mathrm{~g} /$ pot) and lowest when grown together with red rice plants compared with growing on the monocrop system $(9.32 \mathrm{~g} / \mathrm{pot})$, while the Vima-3 variety showed nonsignificant differences in seed yields between growing together with red rice $(11.66 \mathrm{~g} / \mathrm{pot})$ and growing in monocrop systems (10.09 g/pot). Therefore field testing experiments are required to find more tolerant mungbean varieties for planting together with rice plants in an intercropping system.

Keywords: Mungbean, Cropping Patterns, Aerobic Rice System, Intercropping 


\section{PENDAHULUAN}

Kacang hijau (Vigna radiata (L) Wilczek) merupakan salah satu bahan pangan yang banyak dikonsumsi oleh masyarakat selain beras. Kacang hijau merupakan salah satu bahan pangan yang dapat memenuhi kebutuhan dasar manusia karena mengandung unsur makro, mikro, vitamin, asam amino yang dapat memperlancar peredaran darah, kaya akan serat, vitamin A, asam folat, vitamin B1, vitamin B2, protein, karbohidrat, $\mathrm{Ca}$, dan fosfor (Yusuf, 2014). Di masyarakat kebutuhan kacang hijau cukup tinggi karena selain sebagai sumber protein nabati, juga merupakan komoditas strategis yang permintaannya cukup besar setiap tahunnya, selain itu juga dapat dimanfaatkan sebagai bahan pangan, pakan dan industri (Alfandi, 2015).

Sampai saat ini permintaan terhadap kacang hijau terus mengalami peningkatan seiring dengan bertambahnya jumlah penduduk, namun produksi kacang hijau belum mampu memenuhi kebutuhan masyarakat. Menurut Badan Pusat Statistik (2016), produksi kacang hijau pada tahun 2015 mencapai 27.074 ton dan mengalami peningkatan menjadi 41.602 ton pada tahun 2016. Meskipun produksi kacang hijau terus meningkat setiap tahunnya, namun produksi dalam negeri masih belum mampu untuk memenuhi kebutuhan masyarakat. Oleh karena itu, pemerintah masih mengimpor kacang hijau hingga 20,000 ton per tahunnya. Berdasarkan hal tersebut produksi kacang hijau perlu ditingkatkan lagi agar dapat memenuhi kebutuhan masyarakat (Fitriani, 2014).

Usaha untuk meningkatkan produksi kacang hijau dapat dilakukan baik secara intensifikasi maupun ekstensifikasi. Namun demikian, ekstensifikasi hanya dapat dilakukan ke lahan-lahan yang kurang produktif dan tidak beririgasi. Bahkan di lahan sawah saja, kacang hijau pada umumnya ditanam pada musim kemarau saat ketersediaan air tidak cukup untuk menanam padi. Oleh karena itu, produktivitas umumnya rendah. Untungnya kacang hijau merupakan tanaman yang berumur genjah (pendek), toleran terhadap kekeringan karena berakar dalam dan dapat tumbuh pada lahan yang miskin unsur hara. Hal ini karena kacang hijau merupakan tanaman legume yang dapat bersimbiosis dengan bakteri Rhizobium untuk menambat $\mathrm{N}$ udara (Alfandi, 2015). Dengan perluasan (ekstensifikasi) tanam kacang hijau cocok dilakukan ke arah lahan kering.

Tanaman pokok lainnya yang umumnya ditanam di lahan kering terutama pada musim hujan adalah padi gogo. Salah satu jenis padi gogo adalah padi beras merah, dan hampir semua varietas padi beras merah merupakan varietas padi gogo, sehingga dapat ditanam di lahan kering (Mufidah, 2017). Sama halnya dengan padi beras merah, kacang hijau juga merupakan tanaman yang tahan terhadap kekeringan. Mengingat kacang hijau merupakan anggota dari keluarga Leguminoseae, maka tanaman kacang hijau dapat digunakan untuk meningkatkan kesuburan tanah karena kemampuannya bersimbiosis dengan bakteri Rhizobium untuk melakukan fiksasi $\mathrm{N}$ udara. Beberapa peneliti melaporkan adanya transfer $\mathrm{N}$ dari tanaman legume ke serealia dalam sistem tumpangsari serealia-legume, seperti yang dilaporkan oleh Fujita et al. (1990) antara sorghum dan kedelai, Chu et al. (2004) antara padi sistem aerobik dan kacang tanah, dan Inal et al. (2007) antara jagung dan kacang tanah. Inal et al. (2007) melaporkan bahwa pada rizosfir tanaman jagung dan kacang tanah dalam tumpangsari terjadi peningkatan ketersediaan unsur hara, sehingga meningkatkan serapan hara oleh kedua tanaman, terutama P, K, dan Zn.

Tanaman serealia yang ditumpangsarikan dengan tanaman legume juga dilaporkan meningkat serapan N-nya karena ada transfer N dari tanaman legume ke tanaman serealia (Fujita et al., 1990; Inal et al., 2004). Laju transfer $\mathrm{N}$ dari tanaman legume ke non-legume dalam sistem tumpangsari lebih meningkat dengan adanya keterlibatan FMA yang menginfeksi akar kedua tanaman yang ditumpangsarikan (Bethlenvalvay et al., 1991; Hamel dan Smith, 1991). Berdasarkan temuan-temuan tersebut, maka perlu penanaman bersama atau tumpangsari antara padi gogo dan kacang hijau untuk meningkatkan nutrisi $\mathrm{N}$ tanaman padi, tetapi jika ingin dilakukan terhadap padi sawah maka penanaman harus dilakukan dengan sistem irigasi aerobik, seperti yang dilaporkan oleh Wangiyana et al. (2018a). Untuk menciptakan sistem tumpangsari seperti itu, yang menguntungkan kedua jenis tanaman, yaitu padi maupun kacang hijau, maka perlu dicarikan varietas kacang hijau yang cocok ditumpangsarikan dengan tanaman padi.

Penelitian ini bertujuan untuk membandingkan pertumbuhan dan komponen hasil berbagai varietas tanaman kacang hijau antara pola penanaman secara monokrop dan penanaman bersama padi beras merah.

\section{METODE PENELITIAN}

\section{Rancangan Percobaan}

Dalam penelitian ini digunakan metode eksperimental dengan melaksanakan percobaan penanaman di pot dalam rumah plastik di lahan petani di dusun Dasan Tebu, Kecamatan Kediri, Kabupaten Lombok Barat dari bulan Juni sampai September. Percobaan ditata menurut Rancangan Acak Lengkap (RAL) dengan 
menguji dua faktor perlakuan yang ditata secara factorial, yaitu varietas kacang hijau (V) terdiri atas 5 varietas (v1= varietas No. 129; v2= varietas Merak; v3= varietas Vima 3; v4= varietas Vima 1; v5= varietas Kenari) dan pola penanaman $(\mathrm{P})$ terdiri atas 2 aras $(\mathrm{p} 1=$ pola tanam tunggal, $\mathrm{p} 2=$ pola penanaman bersama padi beras merah dalam satu pot). Dengan demikian diperoleh 10 kombinasi perlakuan, yaitu v1p1, v1p2, v2p1, v2p2, v3p1, v3p2, v4p1, v4p2, v5p1, v5p2, dan tiap kombinasi perlakuan diulang 3 kali.

\section{Pelaksanaan Percobaan}

Pot sebanyak 30 buah masing-masing dilubangi dengan bor dari samping (2 lubang per pot) setinggi $1 \mathrm{~cm}$ di atas dasar pot (diameter lubang $9 \mathrm{~mm})$, kemudian tiap pot diisi dengan tanah $(6,5 \mathrm{~kg} / \mathrm{pot})$ yang telah dikeringanginkan dan diayak sebelumnya menggunakan ayakan pasir berlubang ayak $2 \mathrm{~mm}$. Tanah pengisi pot tersebut diambil dari lahan sawah entisol yang berlokasi di dusun Dasan Tebu, Kecamatan Kediri, Lombok Barat. Teknik penanaman kacang hijau pola tanam bersama padi beras merah (kacang hijau dan padi beras merah ditanam dalam satu pot) dan varietas yang digunakan adalah seperti yang diuraikan dalam Wangiyana et al. (2018a), sedangkan untuk pola tanaman kcang hijau monokrop, dalam satu pot hanya ditanam kacang hijau dengan varietas kacang hijau dan saat tanam yang sama dengan pola tanam kacang hijau bersama padi beras merah (3 minggu setelah tanam padi beras merah). Tanaman kacang hijau, baik pada pola tanam monokrop maupun pola tanam bersama padi beras merah, hanya dipupuk dengan Phonska dengan dosis $200 \mathrm{~kg} / \mathrm{ha}(0,8 \mathrm{~g} / \mathrm{pot})$ yang ditugal pada umur 7 hari setelah tanam (hst). Pengairan dilakukan dengan teknik sub-irrigation, dengan menempatkan pot-pot tanaman di dalam bak kayu yang dilapisi lembaran plastik, yang diisi dengan air sumur dengan mempertahankan tinggi genangan air mencapai 1-3 cm di atas lubang sub-irrigation (lubang samping di atas dasar pot). Panen kacang hijau dilakukan hanya terhadap polong sudah berwarna hitam, yang pertama dilakukan pada saat tanaman berumur 67 hst, secara bertahap, dan pemanenan terakhir pada umur 74 hst. Tanaman padi dipanen dengan menggunakan sabit pada saat tanaman berumur 110 hst.

\section{Variabel pengamatan dan analisis data}

Variabel yang diamati dalam penelitian ini ada dua yaitu variabel pertumbuhan dan komponen hasil tanaman kacang hijau. Variabel pertumbuhan meliputi laju pertambahan tinggi tanaman, tinggi tanaman 70 hst, laju pertambahan jumlah daun dan jumlah daun 70 hst, sedangkan komponen hasil meliputi berat biji kering per pot, berat berangkasan kering per pot dan berat 50 biji kering. Data dianalisis dengan analisis sidik ragam (ANOVA) dan uji Beda Nyata Jujur (BNJ) pada taraf 5\% menggunakan program statistik CoStat for Windows ver. 6.303. Pengaruh interaksi ditampilkan dengan grafik batang menggunakan nilai Mean dan Standard Error (SE) berdasarkan Riley (2001).

\section{HASIL DAN PEMBAHASAN}

Hasil analisis sidik ragam (ANOVA) yang dirangkumkan dalam Tabel 1 menunjukkan bahwa terdapat perbedaan antar varietas kacang hijau dalam hal laju pertumbuhan relatif (LPR) tinggi tanaman, tinggi tanaman 70 hst, hasil biji kering per pot dan berat 50 biji kering, sedangkan pola tanam hanya berpengaruh nyata terhadap LPR tinggi tanaman, tinggi tanaman $70 \mathrm{hst}$, dan berat berangkasan kering per pot. Namun demikian, terdapat pengaruh interaksi antar faktor perlakuan terhadap jumlah daun $70 \mathrm{hst}$ dan berat biji kering per pot, yang mengindikasikan bahwa respon terhadap pola penanaman bervariasi antar varietas kacang hijau yang ditanam.

Berdasarkan pengaruh perlakuan, yang ternyata signifikan terhadap tinggi tanaman (Tabel 2), walaupun terlihat ada perbedaan antar varietas kacang hijau, namun secara umum terlihat bahwa tanaman kacang hijau yang ditanam bersama tanaman padi beras merah mempunyai tinggi yang rata-rata lebih tinggi daripada yang ditanam secara monokrop (tanpa bersama padi). Diduga hal ini terjadi karena tanaman kacang hijau berusaha bersaing dengan tanaman padi beras merah untuk mendapatkan cahaya matahari sehingga menjadi lebih tinggi daripada tanaman kacang hijau yang ditanam secara monokrop, yang juga ditunjang oleh laju pertambahan tinggi tanaman kacang hijau yang lebih tinggi pada tanaman kacang hijau yang ditanam bersama padi dibandingkan dengan yang ditanam secara monokrop.

Tabel 1. Rangkuman hasil ANOVA pengaruh pola tanam bersama padi beras merah terhadap pertumbuhan dan komponen hasil berbagai varietas kacang hijau

\begin{tabular}{llll}
\hline Variabel Pengamatan & Varietas (V) & Pola Tanam (P) & Interaksi \\
\hline Laju pertumbuhan relatif tinggi tanaman & $\mathrm{s}$ & $\mathrm{s}$ & $\mathrm{ns}$ \\
Laju pertumbuhan relatif jumlah daun & $\mathrm{ns}$ & $\mathrm{ns}$ & $\mathrm{ns}$ \\
Tinggi Tanaman 70 hst & $\mathrm{s}$ & $\mathrm{s}$ & $\mathrm{ns}$ \\
Jumlah Daun 70 hst & $\mathrm{ns}$ & $\mathrm{ns}$ & $\mathrm{s}$
\end{tabular}


Berat berangkasan kering per pot

$\begin{array}{lll}\mathrm{ns} & \mathrm{s} & \mathrm{ns} \\ \mathrm{s} & \mathrm{ns} & \mathrm{s} \\ \mathrm{s} & \mathrm{ns} & \mathrm{ns}\end{array}$

Berat 50 biji kering

Tabel 2. Pengaruh varietas dan pola penanaman kacang hijau terhadap variabel pertumbuhan tanaman kacang hijau

\begin{tabular}{|c|c|c|c|c|c|c|c|}
\hline \multirow{3}{*}{$\begin{array}{l}\text { Perlakuan } \\
\text { V1-No } 129\end{array}$} & \multirow[b]{2}{*}{$\begin{array}{l}\text { Tinggi tanaman } \\
70 \text { HST }(\mathrm{cm})\end{array}$} & \multirow{2}{*}{\multicolumn{2}{|c|}{$\begin{array}{c}\text { Jumlah daun per } \\
\text { tanaman } 70 \\
\text { HST (helai) }\end{array}$}} & \multicolumn{4}{|c|}{ Laju pertumbuhan relative (LPR) } \\
\hline & & & & \multicolumn{2}{|c|}{$\begin{array}{l}\text { Tinggi tanaman } \\
(\mathrm{cm} / \mathrm{cm} / \mathrm{mingg} \\
\mathrm{u})\end{array}$} & \multicolumn{2}{|c|}{$\begin{array}{l}\text { Jumlah daun } \\
\text { (helai/helai/min } \\
\text { ggu) }\end{array}$} \\
\hline & $52,48 \mathrm{a}$ & 10,8 & $\mathrm{a}$ & 0,214 & $\mathrm{ab}$ & 0,168 & $\mathrm{a}^{1)}$ \\
\hline V2-Merak & $48,42 \mathrm{a}$ & 15,8 & $\mathrm{a}$ & 0,231 & $\mathrm{a}$ & 0,202 & $\mathrm{a}$ \\
\hline V3-Vima3 & $50,12 \mathrm{a}$ & 14,0 & $\mathrm{a}$ & 0,205 & $a b$ & 0,186 & $\mathrm{a}$ \\
\hline V4-Vimal & $34,02 \mathrm{~b}$ & 13,0 & $\mathrm{a}$ & 0,186 & $\mathrm{~b}$ & 0,173 & $\mathrm{a}$ \\
\hline V5-Kenari & $45,70 \mathrm{ab}$ & 15,0 & $\mathrm{a}$ & 0,209 & $a b$ & 0,179 & $\mathrm{a}$ \\
\hline BNJ 5\% & 11,88 & 5,3 & & $\mathbf{0 , 0 3 7}$ & & 0,053 & \\
\hline P1-Monokrop & $37,41 \mathrm{~b}$ & 14,7 & $\mathrm{a}$ & 0,191 & $\mathrm{~b}$ & 0,19 & $\mathrm{a}$ \\
\hline P2-Bersama padi & $54,89 \mathrm{a}$ & 12,8 & $\mathrm{a}$ & 0,227 & $\mathrm{a}$ & 0,173 & $\mathrm{a}$ \\
\hline BNJ 5\% & 5,24 & 2,3 & & 0,016 & & 0,024 & \\
\hline
\end{tabular}

${ }^{1)}$ Angka-angka pada setiap kolom yang diikuti huruf yang sama, tidak berbeda nyata menurut uji BNJ pada taraf nyata $5 \%$

Sebaliknya, terhadap jumlah daun dan laju pertambahan jumlah daun kacang hijau, tidak terdapat pengaruh kedua faktor perlakuan (Tabel 2). Namun demikian, ada pengaruh interaksi antara kedua faktor perlakuan terhadap jumlah daun 70 hst seperti terlihat dalam Gambar 1, yang menunjukkan respon berbeda antara dua kelompok varietas kacang hijau terhadap penanaman bersama tanaman padi beras merah dalam satu pot. Tanaman kacang hijau varietas No.129 menghasilkan jumlah daun 70 hst yang lebih banyak pada penanaman bersama padi beras merah dibandingkan dengan penanaman secara monokrop. Sebaliknya, varietas Vima-1 menunjukkan jumlah daun 70 hst pada penanaman bersama padi beras merah yang kurang dari 50\% dari jumlah daunnya pada penanaman secara monokrop. Hal ini menunjukkan bahwa varietas Vima-1 tidak toleran terhadap naungan oleh tanaman padi beras merah yang tingginya rata-rata lebih tinggi dari tinggi tanaman kacang hijau. Selain itu, tinggi tanaman kacang hijau varietas Vima-1 juga lebih rendah dibandingkan dengan varietas No.129 (Tabel 2), yang menyebabkan tanaman kacang hijau varietas Vima-1 lebih ternaungi oleh tanaman padi beras merah dibandingkan dengan varietas No.129, karena rata-rata tinggi tanaman padi beras merah mencapai $90 \mathrm{~cm}$ (Wangiyana et al., 2018b).

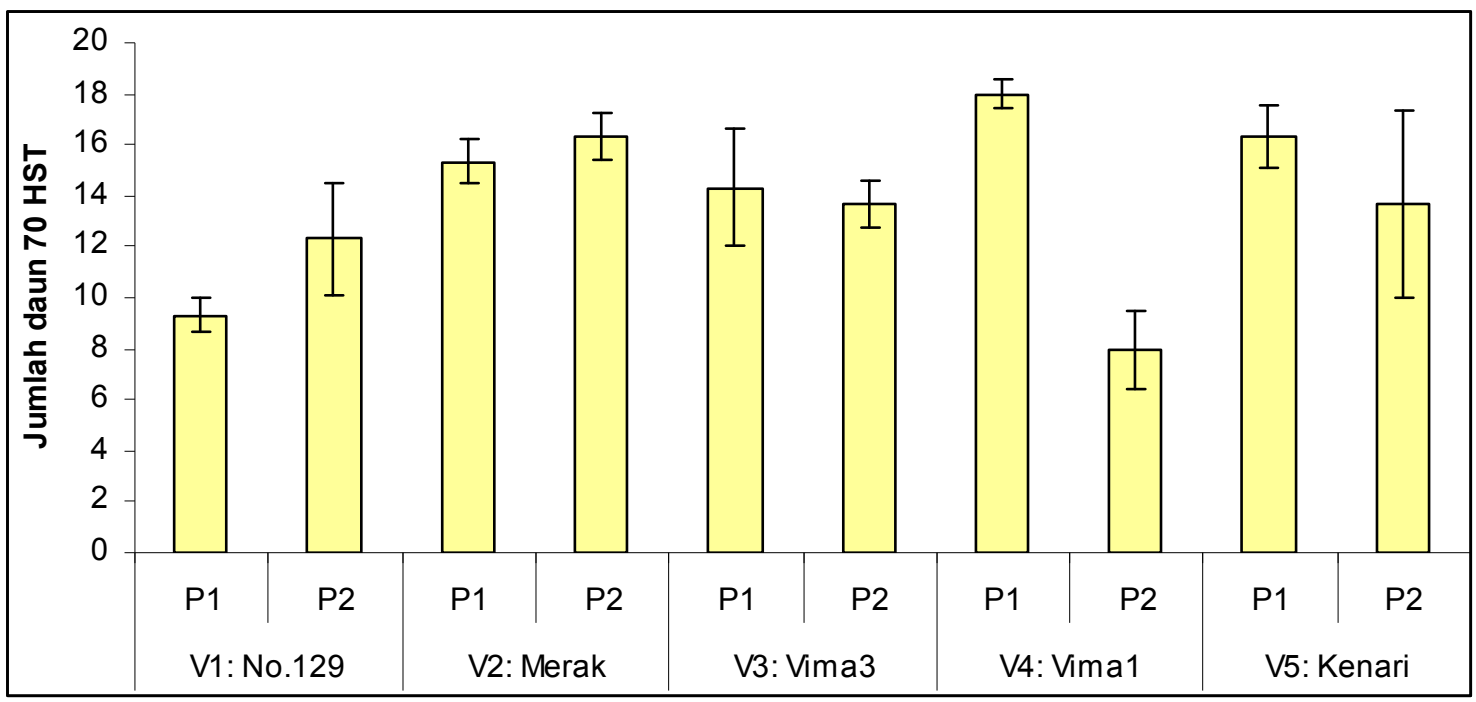

Gambar 1. Rerata (Mean \pm SE) jumlah daun per tanaman berbagai varietas kacang hijau antara penanaman secara monokrop (P1) dan penanaman bersama padi beras merah (P2) 
Demikian pula terhadap hasil biji kering tanaman kacang hijau per pot, terdapat penngaruh interaksi antara kedua faktor perlakuan, seperti dapat dilihat dari Gambar 2, yang menunjukkan bahwa respon berbagai varietas kacang hijau terhadap penanaman bersama padi beras merah bervariasi tergantung pada varietas kacang hijau yang ditanam, walaupun secara rata-rata tidak ada perbedaan hasil biji kering tanaman kacang hijau antara penanaman bersama padi dan penanaman secara monokrop (Tabel 3).

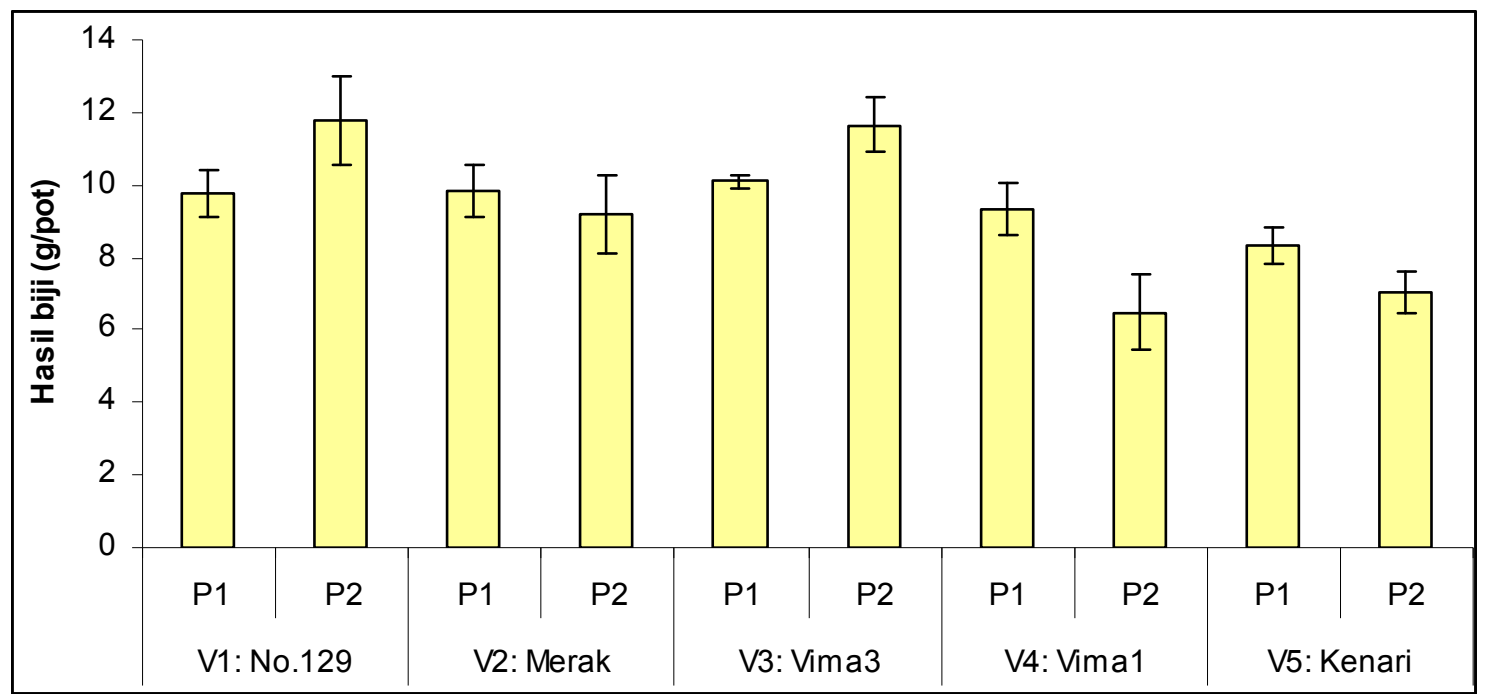

Gambar 2. Rerata (Mean \pm SE) hasil biji kering (g/pot) berbagai varietas kacang hijau antara penanaman secara monokrop (P1) dan penanaman bersama padi beras merah (P2)

Tabel 3. Pengaruh varietas dan pola penanaman kacang hijau terhadap komponen hasil tanaman kacang hijau

\begin{tabular}{lcclrr}
\hline Perlakuan & $\begin{array}{c}\text { Hasil berat biji kering (g/ } \begin{array}{c}\text { Berat berangkasan kering } \\
\text { pot) }\end{array} \\
(\mathrm{g} / \text { pot) }\end{array}$ & 7,52 & $\mathrm{a}$ & 2,97 & $\mathrm{ab}{ }^{1)}$ \\
\hline V1-No.129 & $10,79 \mathrm{a}$ & 6,33 & $\mathrm{a}$ & 2,55 & $\mathrm{~b}$ \\
V2-Merak & $9,50 \mathrm{ab}$ & 11,23 & $\mathrm{a}$ & 2,65 & $\mathrm{~b}$ \\
V3-Vima3 & $10,88 \mathrm{a}$ & 5,87 & $\mathrm{a}$ & 2,56 & $\mathrm{~b}$ \\
V4-Vima1 & $7,91 \mathrm{~b}$ & 9,48 & $\mathrm{a}$ & 3,14 & $\mathrm{a}$ \\
V5-Kenari & $7,69 \mathrm{~b}$ & 6,50 & & 0,49 & \\
BNJ 5\% & 2,38 & 6,27 & $\mathrm{~b}$ & 2,75 & $\mathrm{a}$ \\
P1-Monokrop & $9,47 \mathrm{a}$ & 9,91 & $\mathrm{a}$ & 2,80 & $\mathrm{a}$ \\
P2-Bersama padi & $9,23 \mathrm{a}$ & 2,87 & & 0,22 & \\
BNJ 5\% & 1,05 & & &
\end{tabular}

${ }^{1)}$ Angka-angka pada setiap kolom yang diikuti huruf yang sama, tidak berbeda nyata menurut uji BNJ pada taraf nyata $5 \%$

Dari Gambar 2 dapat dilihat bahwa tanaman kacang hijau varietas No.129 dan Vima-3 menunjukkan hasil biji per pot yang lebih tinggi pada penanaman bersama padi beras merah dibandingkan dengan penanaman secara monokrop. Sebaliknya tanaman kacang hijau varietas Vima-1 dan Kenari bahkan menunjukkan penurunan hasil biji kering yang sangat signifikan akibat penanaman bersama padi beras merah dibandingkan dengan penanaman secara monokrop. Hal ini diduga berkaitan dengan tinggi tanaman kedua varietas kacang hijau ini yang lebih rendah dibandingkan dengan ketiga varietas kacang hijau lainnya, terutama varietas No.129 (Tabel 2), kemungkinan menyebabkan tanaman kacang hijau dari kedua varietas ini menjadi lebih ternaungi oleh tanaman padi beras merah dibandingkan dengan varietas No.129, sehingga hasil biji kedua varietas ini, terutama Vima-1, menjadi lebih rendah dibandingkan dengan hasil biji kacang hijau varietas No.129. Demikian pula halnya dengan berat berangkasan dan berat 100 biji kering, paling rendah pada varietas Vima-1, yang diduga akibat kemampuan bersaing varietas Vima-1 yang paling rendah dengan tanaman padi beras merah, yang kemungkinan akibat jumlah daunnya yang paling redah pada penanaman bersama padi beras merah (Gambar 1).

Adanya varietas-varietas kacang hijau yang menunjukkan hasil biji tidak berbeda nyata atau bahkan lebih tinggi pada pola penanaman bersama padi beras merah (Gambar 2) menunjukkan bahwa ada varietas kacang hijau yang cocok ditumpangsarikan dengan padi beras merah, yang dapat digunakan untuk menjaga 
kesuburan tanah, terutama kandungan $\mathrm{N}$ tanah, mengingat kacang hijau merupakan tanaman leguminosease yang dapat membentuk bintil akar dalam simbiosis dengan bakteri Rhizobium untuk melakukan penambatan $\mathrm{N}$ atmosfir menjadi tersedia bagi tanaman maupun tersimpan di dalam bintil akar untuk menyuburkan tanah. Beberapa penelitian tumpangsari tanaman serealia dengan tanaman legume menunjukkan adanya kontribusi $\mathrm{N}$ dari tanaman legume ke tanaman serealia, seperti pada tumpangsari padi dan kacang tanah (Chu et al., 2004). Inal et al. (2007) juga melaporkan bahwa pada rizosfir tanaman jagung dan kacang tanah dalam sistem tumpangsari terjadi peningkatan ketersediaan unsur hara, terutama $\mathrm{P}, \mathrm{K}, \mathrm{Zn}$, Fe, yang mengakibatkan serapan unsur hara oleh kedua tanaman menjadi meningkat.

Namun demikian, dari hasil penelitian Wangiyana et al. (2018a), tampak bahwa varietas kacang hijau berbeda yang ditanam bersama tanaman padi beras merah menunjukkan kontribusi yang berbeda pula terhadap pertumbuhan dan komponen hasil padi beras merah. Dari penelitian ini tampak bahwa kacang hijau varietas No.129 menunjukkan hasil biji tertinggi pada penanaman bersama padi beras merah jika dibandingkan dengan varietas kacang hijau lainnya, dan bahkan hasil bijinya lebih tinggi pada pola penanaman bersama padi beras merah dibandingkan dengan penanaman secara monokrop. Namun, ditinjau dari komponen hasil padi beras merah yang ditanam bersama kacang hijau, ternyata hasil gabah padi mencapai tertinggi pada tanaman padi beras merah yang ditanam bersama kacang hijau varietas Kenari, terutama jika tanaman padi beras merah diinokulasi dengan fungi mikoriza arbuskular (FMA), sedangkan tanaman padi beras merah yang ditanam bersama kacang hijau varietas No.129 menunjukkan hasil gabah yang paling rendah (Wangiyana et al., 2018a).

Oleh karena itu, maka sangat perlu dilakukan penelitian-penelitian lebih lanjut, terutama di lapangan, untuk menemukan varietas-varietas kacang hijau yang paling toleran untuk ditanam dalam sistem tumpangsari dengan tanaman padi, tentunya pada sistem aerobik, namun mampu memberikan kontribusi yang tinggi terhadap peningkatan hasil padi dan terhadap kesuburan tanah, terutama kandungan $\mathrm{N}$ tanah.

\section{KESIMPULAN}

Berdasarkan hasil penelitian dapat disimpulkan bahwa ada perbedaan respon antar beberapa varietas kacang hijau terhadap pola penanaman bersama padi beras merah dalam kaitan dengan pertumbuhan dan hasil biji kacang hijau. Kacang hijau varietas No.129 menunjukkan hasil biji yang lebih tinggi pada pola penanaman bersama padi beras merah (11,78 g/pot), sebaliknya varietas Vima-1 hasil bijinya lebih rendah dan terendah $(6,5 \mathrm{~g} / \mathrm{pot})$ pada penanaman bersama padi beras merah dibandingkan pada sistem monokrop, sedangkan varietas Vima-3 menunjukkan hasil biji yang tidak berbeda nyata antara penanaman bersama padi beras merah (11,66 g/pot) dibandingkan sistem monokrop (10,09 g/pot). Oleh karena itu perlu pengujian lapangan untuk menemukan lebih banyak lagi varietas kacang hijau yang toleran untuk ditanam bersama padi pada sistem tumpangsari.

\section{UCAPAN TERIMA KASIH}

Data yang dilaporkan dalam artikel ini merupakan bagian dari salah satu percobaan dalam penelitian tahun pertama dari penelitian desentralisasi pada skim PTUPT yang didanai oleh Direktorat Riset dan Pengabdian Masyarakat, Kementerian Riset, Teknologi, dan Pendidikan Tinggi, dengan kontrak No. 074/SP2H/LT/DRPM/IV/2017; oleh karena itu penulis menyampaikan banyak terima kasih atas dana hibah penelitian PTUPT yang telah diberikan.

\section{DAFTAR PUSTAKA}

Alfandi, 2015. Kajian Pertumbuhan dan Hasil Tanaman Kacang Hijau (Phaseolus radiates L.) Akibat Pemberian Pupuk P dan Inokulasi Cendawan Mikoriza Arbuskula (CMA). Agrijati 28(1): 158-171.

Badan Pusat Statistik. 2016. Produksi Kacang Hijau Menurut Provinsi. Rakor Solo. Jateng.

Bethlenfalvay, G.J., M.G. Reyes-Solis, S.B. Camel, and R. Eerrera-Cerrato, 1991. Nutrient transfer between the root zones of soybean and maize plants connected by a common mycorrhizal mycelium. Physiologia Plantarum, 82: 423-432.

Chu, G.X., Q.R. Shen, and J.L. Cao, 2004. Nitrogen fixation and N transfer from peanut to rice cultivated in aerobic soil in an intercropping system and its effect on soil N fertility. Plant and Soil, 263: 17-27.

Fitriani, A., 2014. Pengaruh Pemberian Pupuk Cair Limbah Organik terhadap Pertumbuhan Kacang Hijau (Phaseolus radiatus L.). [Skripsi, unpublished]. Fakultas Keguruan dan Ilmu Pendidikan Universitas Bengkulu. Bengkulu. 
Fujita, K., S. Ogata, K. Matsumoto, T. Masuda, G.K. Ofosu-Budu, and K. Kuwata, 1990. Nitrogen Transfer and Dry Matter Production in Soybean and Sorghum Mixed Cropping System at Different Population Density. Soil Sci. Plant Nutr., 36(2): 233-241.

Hamel, C. and D.L. Smith, 1991. Interspecific N-transfer and plant development in a mycorrhizal fieldgrown mixture. Soil Biology and Biochemistry, 23: 661-665.

Inal, A., A. Gunes, F. Zhang, and I. Cakmak, 2007: Peanut/maize intercropping induced changes in rhizosphere and nutrient concentrations in shoots. Plant Physiology and Biochemistry, 45: 350-356

Mufidah H. 2017. Pengaruh Abu Sekam Terhadap Pertumbuhan Vegetatif dan Struktur Anatomis Daun Padi Merah (Oryza sativa L.) 'Segreng' pada Cekaman Kekeringan. [Skripsi, unpublished]. Fakultas Biologi Universitas Gadjah Mada. Yogyakarta. Indonesia.

Riley, J., 2001. Presentation of statistical analyses. Experimental Agriculture, 37: 115-123.

Wangiyana, W., I.G.P.M. Aryana, I.G.E. Gunartha, dan N.W.D. Dulur, 2018a. Pengaruh Inokulasi Mikoriza terhadap Komponen Hasil Padi Sistem Pengairan Aerobik yang Ditumpangsarikan dengan Kacang Hijau. Agritech (UGM), 38(3): 289-294.

Wangiyana, W., I.G.P.M. Aryana, and N.W.D. Dulur, 2018b. Effect of Mycorrhiza Application with Reduced NPK Fertilizers on Growth and Yield of Several Promising Lines of Red Rice in Aerobic System. IOSR-Journal of Agriculture and Veterinary Science, 11(12, ver. II): 54-59.

Yusuf, 2014. Pemanfaatan Kacang Hijau sebagai Pangan Fungsional Mendukung Diversifikasi Pangan di Nusa Tenggara Timur. Prosiding Seminar Hasil Penelitian Tanaman Aneka Kacang dan Umbi. Halm. 741-742. 